\title{
Solid State Fermentation of Wheat Straw Admixture with Cattle Dung for Biogas Production
}

\author{
R. S. Khoiyangbam \\ Department of Forestry \& Environmental Science, Manipur University, Canchipur, Imphal (Manipur) - 795 003, India
}

\begin{abstract}
Biomethanation of wheat straw admixture with cattle dung was experimented under Total solids (TS) concentration of $22 \%$ in five batch fed digesters $\left(1.5 \mathrm{~m}^{3}\right)$ to evaluate the biogas production potentiality. The combined gas production in the digesters mixed fed with wheat straw and cattle dung in the ratio of 1:2 on dry weight basis ranged between 1023 and 3654 L/day. Pre-treatment of the wheat straw prior to biomethanation with $0.03 \% \mathrm{NaOH}$ solution enhanced the biogas yield by 1.25 times. The correlation between the ambient temperature and biogas production was positive and statistically significant for both the NaOH pre-treated wheat straw $\left(R^{2}=0.79\right)$ and wheat straw devoid of $\mathrm{NaOH}$ pre-treatment $\left(R^{2}=0.77\right)$ admixture with cattle dung.
\end{abstract}

Keywords: Solid state fermentation, wheat straw, cattle dung, chemical treatment.

\section{Introduction}

Biomethanation of agricultural wastes is one of the appropriate recycling technologies to meet the present fuel energy and fertilizer crises in agrarian countries like India where the availability of the plant residues is substantial [1][3]. The conventional biogas plants popular in India namely, KVIC, Janata and Deenbandhu are designed to work on cattle dung at the total solids content ranging between 8 to 12 $\%$ and the Hydraulic Retention Time (HRT) of 40-55 days [4]. Within this retention time the cattle dung undergoes anaerobic fermentation inside the biogas plant in three phases [5]. Charging agricultural waste as feed load pose constant problems of mixing and scum formation and thereby production of biogas [6].

In India, annually 258 million tonnes of straw and about 354 million tonnes of cattle dung are generated. During the last few decades concentrated efforts have been made to develop solid state fermenters which are workable on agricultural wastes alone or in supplementation with cattle dung. Solid state fermenters can become a space efficient, high rate digestion system for digesting agricultural wastes [7]. Agricultural wastes like wheat straw contains lingo-cellulosic fraction. Lignin is considered to have no methanogenic potential, because it lowers the digestibility of substrates with which it is associated [8]. Sodium hydroxide is a known delignifying agent and has been used in a variety of material to improve their digestibility [9].

\section{Methodology}

\section{1 $\mathrm{NaOH}$ pre-treated wheat straw}

Dry wheat straw was chemically treated with $\mathrm{NaOH}$ before utilizing it for biomethanation. The straw was soaked in 0.03 $\% \mathrm{NaOH}$ solution for $24 \mathrm{hrs}$ and latter on washed with water continuously to neutralize it. Subsequently, the straw was dried in room air to reduce the moisture content upto 30-35 $\%$. The dried straw was then chopped to $\sim 10-15 \mathrm{~mm}$ pieces before mixing with the cattle dung for digestion.

\subsection{Measurement of biogas yield}

The $\mathrm{NaOH}$ pre-treated straw was mixed with cattle dung in the ratio of 1:2 on dry weight basis. The total solids in the feed material were maintained at $22 \%$. The mixed residues were then fed into a digester of the capacity of $\left(1.5 \mathrm{~m}^{3}\right)$. Four other digesters of the same capacity were fed consecutively one after other every 12 days in the same pattern. Similarly, a series of five digesters were set up with wheat straw (without $\mathrm{NaOH}$ pre-treatment) admixture with cattle dung. In all the plants the loaded substrate remains in the digester for 60 days (HRT), after which it was replaced by new feed load on the same day. The operation remains cyclic, and at any time five digesters each of $\mathrm{NaOH}$ treated and untreated wheat straws were working simultaneously. All the five plants were connected in series using rubber tubing and gate valves. The per day combined biogas production in the five digesters on similar substrate was recorded separately for the two different batch systems by using gas flow meters for nine months.

\section{Results Analysis}

The results of the experiment on biomethanation revealed that biogas production was consistently higher in the batch system charged with $\mathrm{NaOH}$ pre-treated wheat straw admixture with cattle dung compared to that of the batch system charged with untreated wheat straw and cattle dung (Fig. 1). The average cumulative gas yield throughout the study period in the $\mathrm{NaOH}$ pretreated and untreated wheat straws were $2392 \mathrm{~L} /$ day and $2998 \mathrm{~L} /$ day, respectively. This corresponds to an improvement of biogas yield by $125.33 \%$ in the batch system charged with $\mathrm{NaOH}$ pretreated substrate. The improvement in digestion of the straw due to delignification as a result of $\mathrm{NaOH}$ treatment might have attributed to the higher yield of biogas in these digesters.

Mital [7] reported that sodium hydroxide has been one of the most popular agents for delignification which improves the digestibility to a variety of material. Furthermore, the shredding of the straw had reduced the substrate sizes thereby increasing the surface area and rendering it more 


\section{International Journal of Science and Research (IJSR) \\ ISSN (Online): 2319-7064}

Index Copernicus Value (2013): 6.14 | Impact Factor (2014): 5.611

susceptible to bacterial invasion for digestion. This physical treatment had enhanced the digestion process in both the batch systems. It may be noted that the significance of pretreatment was more pronounce during the warmer summer months and lesser with fall of temperature.

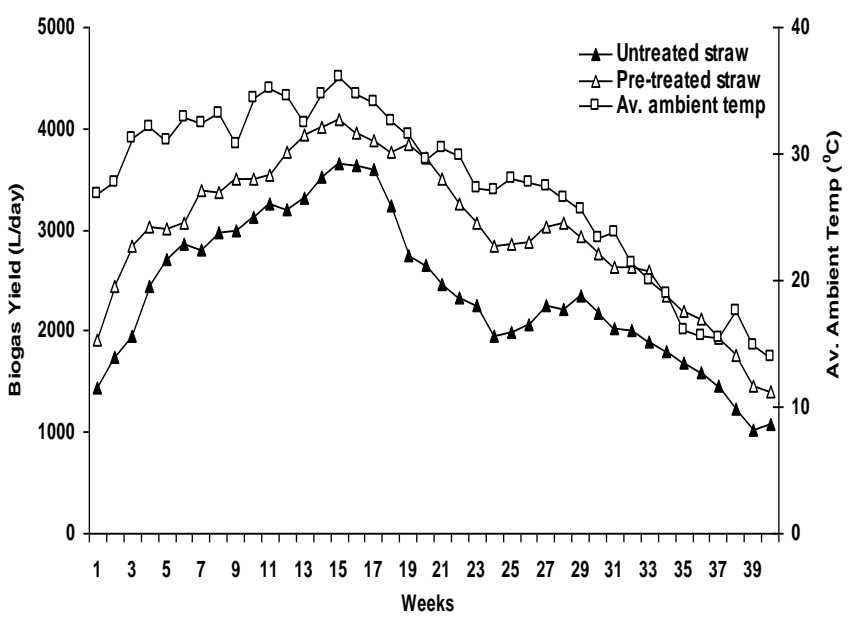

Figure 1: Average cumulative gas production in the batch fed digesters

The data reflects a strong influence of seasonal changes in temperature on the biomethanation activities. In anaerobic digesters certain specialized microorganisms are known to perform the methanogenic stage and they are very sensitive towards any temperature change [10]. Any shift of the temperature away from the optimum mesophilic range affects the performance of the digester. During the first week of our measurement, when all the five plants started functioning, the average ambient temperature recorded was $26.8^{\circ} \mathrm{C}$, and the biogas production from the pre-treated and untreated substrate was 1915 L/day and 1433 L/day, respectively (Fig. $1)$.

The biogas yield in both the batch systems improved considerably in the subsequent weeks, the highest production for the pre-treated substrate (4099 L/day) and untreated substrate $\left(3654 \mathrm{~L} /\right.$ day) were recorded in the $15^{\text {th }}$ week, during the month of July, when the average ambient temperature reached $36.0{ }^{\circ} \mathrm{C}$. The following weeks showed a decrease in biogas yield. During the $40^{\text {th }}$ week, during the month of December the gas yield was $1401 \mathrm{~L}$ /day from the pre-treated straw and $1088 \mathrm{~L} /$ day from the untreated straw. The steep fall in the gas productions in the initial and ending weeks of the experiment were due to decrease in temperature during these weeks. Most isolates of methanogenic bacteria are mesophilic, having temperature optima of $30-40^{\circ} \mathrm{C}$. Deviation from the optimum temperature range might have attributed the lower gas yields in the initial and the finishing weeks of the experiment. The correlation between the ambient temperature and biogas production was positive and statistically significant for both the $\mathrm{NaOH}$ pre-treated wheat straw $\left(R^{2}=0.79\right)$ and $\mathrm{NaOH}$ untreated wheat straw $\left(R^{2}=0.77\right)$ admixture with cattle dung (Fig. 2).

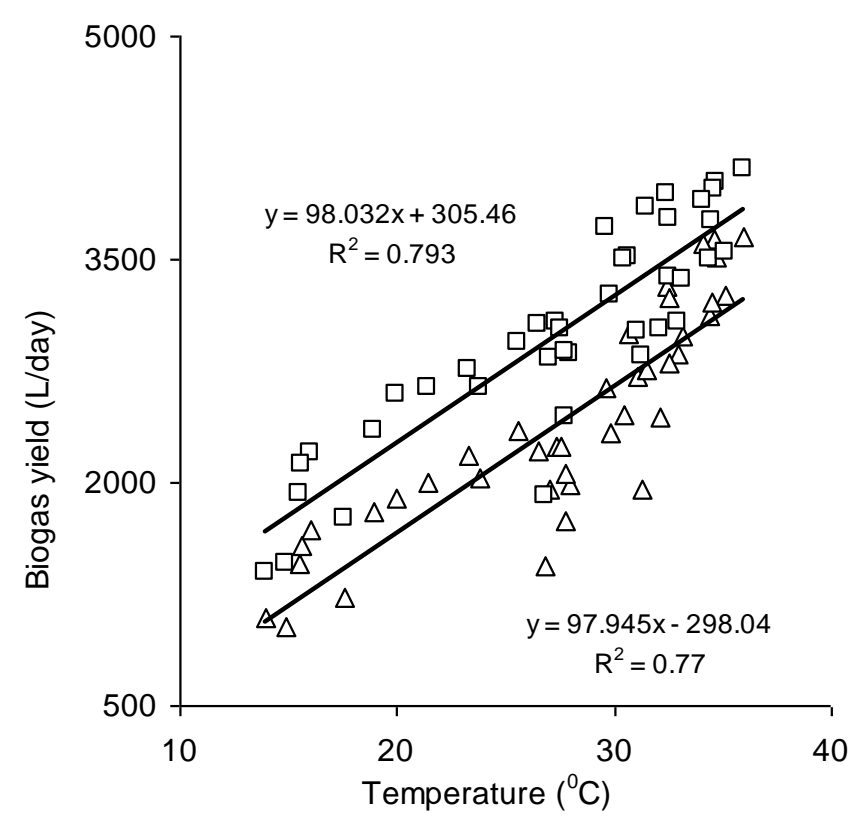

Figure 2: Biogas production from wheat straw pre-treated [ם] and untreated $[\Delta]$ with $\mathrm{NaOH}$ plotted against ambient temperature

\section{Conclusions}

Wheat and rice straw are widely available agricultural wastes in India that accounts to $70 \%$ of total crop residues produced. Biomethanation technology successfully utilizing wheat and rice straws remains a challenge to the researchers due to the problems arising from scum formation and blockage of the digester. Solid state fermentation is free from such problems and has additive advantages of lesser space requirement for storage and drying of sludge. The results of the present study convincingly indicate that biomethanation of wheat straw can be successfully carried out in the batch fed digesters with cattle dung at a Total solids concentration up to $22 \%$. Chemical treatment of the wheat straw in $\mathrm{NaOH}$ prior to digestion improved the biogas yield by 1.25 times.

\section{References}

[1] Devianai, K., Kasturi Bai, R., "Batch biomethanation of Banana Trash and Coir Pith," Bioresource Technology, LII, pp. 93-94, 1995.

[2] R.S. Khoiyangbam, S. Kumar, N. Gupta. Biogas Technology: Towards Sustainable Development, New Delhi: The Energy and Resources Institute (TERI), 2011.

[3] R. S. Khoiyangbam, "Environmental implications of biomethanation in conventional biogas plants," Iranica Journal of Energy \& Environment, II (2), pp. 181-187, 2011.

[4] M. C. Jain, "Bioconversion of organic wastes for fuel and manure". Fert. News, XXXVII (4), pp. 55-61, 1993.

[5] R. S. Khoiyangbam, "Greenhouse gases emission from energy production in conventional biogas plants in India”. Energy sources, Part A; Recovery, Utilization, and Environmental effects, XXX, pp. 689-697, 2008. 
[6] M. Shyam, "Horizontal flow biogas plant for lingo cellulosic biomass. AICRP on Renewable Sources of Energy", CIAE, Bhopal, India, 2002.

[7] Zhang RuiHong, Zhang ZhiQin, Zhang R. H., Zhang, Z. Q., Biogasification of rice straw with an anaerobic phase solids digester system. ASAE Annual International Meeting, Minneapolis, Minnesota, USA, 10-24 August, 1997. American Society of Agricultural Engineers. No. 976083, 17pp. 1997.

[8] Kosaric, N., Velikonja, J., "Liquid and gaseous fuels from biotechnology: challenges and opportunities". FEMS Microbiology Review, XVI, pp. 111-42, 1995.

[9] K. M. Mital, Biogas systems, Principles and applications. New Age International (P) Limited, New Delhi, India, 1996.

[10] K. V. Rajeshwari, M. Balakrishnan, A. Kansal, K. Lata, V. V. N. Kishore, "State-of-the-art of anaerobic digestion technology for industrial wastes water treatment". Renewable and Sustainable Energy Reviews, IV, pp. 135-56, 2002.

\section{Author Profile}

R. S. Khoiyangbam did his M.Sc. in Environmental Sciences from GJ University, Haryana and $\mathrm{PhD}$ in Environmental Sciences from IARI, New Delhi. He had worked as Research Associate at IARI and GBPIHED, Himachal Pradesh. He then worked as Assistant Professor in Bundelkhand University, Uttar Pradesh and in DM College of Science, Manipur. $\mathrm{He}$ is now working as Assistant Professor in Department of Forestry \& Environmental Science, Manipur University. 